\title{
Rudolf Barth: um cientista pioneiro na ilha da Trindade
}

\author{
Rudolf Barth: a pioneering scientist on \\ the island of Trindade
}

\section{Ortrud Monika Barth}

Pesquisadora, chefe do Laboratório de Morfologia e Morfogênese Viral/ Instituto Oswaldo Cruz/Fiocruz. Av. Brasil, 4365

21040-900 - Rio de Janeiro - RJ Brasil

barth@ioc.fiocruz.br

\section{Cristina Engel de Alvarez}

Coordenadora do Laboratório de Planejamento e Projetos/ Universidade Federal do Espírito Santo.

Av. Fernando Ferrari, 514 Cemuni I, sala 7 29075-910 - Vitória - ES - Brasil cristina.engel@ufes.br
BARTH, Ortrud Monika, ALVAREZ, Cristina Engel de. Rudolf Barth: um cientista pioneiro na ilha da Trindade. História, Ciências, Saúde Manguinhos, Rio de Janeiro, v.19, n.3, jul-set. 2012, p.969-992.

\section{Resumo}

Em consequência da instituição do Ano Geofísico Internacional, em 1957, a Marinha do Brasil organizou uma expedição à ilha da Trindade, da qual participou Rudolf Barth, pesquisador do Instituto Oswaldo Cruz e do Instituto de Pesquisas da Marinha, membro da Academia Brasileira de Ciências e do Conselho Nacional de Pesquisas. Esse cientista retornou à ilha da Trindade no ano seguinte, em uma segunda viagem com a Marinha brasileira. As pesquisas feitas então resultaram em algumas publicações científicas e em dois relatórios inéditos com observações e dados concernentes a fenômenos zoológicos (terrestres), meteorológicos, climatológicos, geomorfológicos e biológicos. Os relatórios são transcritos a seguir.

Palavras-chave: Rudolf Barth (1913-1978); ilha da Trindade; biologia; Instituto de Pesquisas da Marinha; Instituto Oswaldo Cruz.

\section{Abstract}

As a result of the institution of the International Geophysical Year in 1957, the Brazilian Navy organized an expedition to the island of Trindade, on which Rudolf Barth participated. He was a researcher at the Oswaldo Cruz Institute and the Naval Research Institute, and a member of the Brazilian Academy of Sciences and the National Research Council. The scientist returned to the island of Trindade the following year, on a second expedition with the Brazilian Navy. The research findings then resulted in some scientific publications and two unpublished reports with observations and data concerning terrestrial, zoological, meteorological, climatological, geomorphological and biological phenomena. The reports are then transcribed.

Key words: Rudolf Barth (1913-1978); the island of Trindade; biology; Naval Research Institute; Oswaldo Cruz Institute. 
$\mathrm{E}$ m Dortmund, Alemanha, em 30 de março de 1913, nascia Rudolf Barth, terceiro filho do pastor luterano Friedrich C. E. Barth e de Lina Barth. Desde cedo, influenciado pelo pai, um amante da natureza, Barth foi estudioso da história natural, exercitando sua capacidade de observação em longas caminhadas ou passeios de bicicleta. Numa dessas excursões, à beira de bucólico lago do norte da Alemanha, encontrou a futura esposa, Lilli Charlotte Wilhelmine Meyer, tendo ambos então 17 anos de idade. Casaram-se em 1938, após a conclusão de seus estudos, e durante a Segunda Guerra Mundial nasceram os dois filhos do casal: Ortrud Monika, em 1939, e Ulrich, em 1943.

Rudolf Barth doutorou-se em zoologia na Universidade de Bonn em 1937, sob a orientação de August Reichensperger, e, no ano seguinte, ocupou cargo de chefia num órgão regional da Defesa Sanitária Vegetal do Ministério da Agricultura, na cidade de Donaueschingen, no sul da Alemanha.

Com a eclosão da guerra nesse mesmo ano, foi enviado para a França, mas quando nasceu a filha, concederam-lhe uma licença, curta e providencial, pois naquele ínterim foi exterminado o pelotão de artilharia do qual fazia parte.

Durante a guerra, Barth estudou física teórica na Universidade de Berlim (1941) e meteorologia, nessa cidade e em Lüben (1941-1942). Quando trabalhava como meteorologista no aeroporto de Berlim, ficou soterrado durante um ataque aéreo ao aeroporto, o que lhe deixou como sequela, pelo resto da vida, a claustrofobia. Foi prisioneiro dos ingleses num campo de concentração na Dinamarca e lá contraiu malária. Terminada a guerra, voltou a pé para casa. Conseguiu emprego na firma Boehringer-Ingelheim (1948-1949) e, nas horas vagas, escreveu Der einbändige Brehm ${ }^{1}$, resumindo num único livro o conteúdo dos 13 volumes de Brehms Tierleben, de Alfred Edmund Brehm, renomada enciclopédia de zoologia que começara a ser publicada nos anos 1860.

Com a ajuda do irmão mais velho, que residia no Rio de Janeiro, Hans Christian Barth, da filial da firma Bayer, Rudolf Barth emigrou para o Brasil com a esposa e os dois filhos. Em dezembro de 1949, no porto de Hamburgo, embarcaram num navio de guerra brasileiro, e na manhã de 6 de janeiro de 1950 a família desembarcou no cais da praça Mauá.

Rudolf Barth trazia carta de apresentação de seu orientador em Bonn para o padre Thomas Borgmeier, franciscano do Convento de Santo Antônio no Rio de Janeiro e especialista em formigas, que apresentou o zoólogo alemão a Olympio da Fonseca, então diretor do Instituto Oswaldo Cruz. Já em março de 1950, Barth ingressava no Instituto com bolsa do Ministério da Saúde.

Colaborou ativamente na implantação e, por vários anos, no desenvolvimento do Laboratório de Pesquisas Biológicas do Instituto de Pesquisas da Marinha. Respeitoso e paciente, formou uma nova geração de pesquisadores em ambas as instituições. $\mathrm{O}$ reconhecimento de seu talento como cientista veio através de numerosas medalhas e ao ocupar ele a vaga de Henrique da Rocha Lima na Academia Brasileira de Ciências. Rudolf Barth publicou quatro livros e estava já muito doente quando concluiu os últimos dos 190 artigos científicos que publicou. Faleceu em Petrópolis, em 1ํ de janeiro de 1978. Um resumo de sua vida,

\footnotetext{
${ }^{1}$ Berchtesgaden, Zimmer \& Herzog, 1953.
} 
incluindo a lista completa de suas publicações, foi divulgado por sua filha, também pesquisadora do Instituto Oswaldo Cruz desde 1962 (Barth-Schatzmayr, 2001). ${ }^{2}$

Em consequência da instituição do Ano Geofísico Internacional, em 1957, a Marinha Brasileira organizou expedições à ilha da Trindade, das quais o doutor Barth, como era chamado, participou com entusiasmo. Os trabalhos ora publicados são relatórios técnicos produzidos em duas expedições. A primeira ocorreu no período de 26 de agosto a 13 de setembro de 1957, a bordo do Navio-Escola (NE) Almirante Saldanha, e representou permanência relativamente longa e produtiva no local. A segunda, de 23 a 29 de junho de 1958, a bordo da corveta Solimões, com permanência de apenas um dia, possibilitou observações para complementar os estudos anteriormente realizados. Nesta última expedição, Barth foi acompanhado pelo colega do Instituto Oswaldo Cruz, o engenheiro-agrônomo Henrique Pimenta Veloso.

Barth produziu ricas descrições, complementadas por fotografias e diapositivos, sobre a fauna e flora da ilha de Trindade: pássaros, tartarugas, porcos e cabritos, os insetos, seu objeto de predileção, a vegetação dizimada pelos navegantes que lá aportaram e a mata remanescente de fetos (samambaias) arborescentes, que o encantou.

Em certos momentos, sua escrita é leve e graciosa, mistura poesia e ciência, deixando assim menos herméticos os caminhos do conhecimento. Mesmo quando adota a escrita leve e personalizada, as informações técnicas são precisas, e o caráter científico das observações, irretocável.

Suas observações possibilitam importantes reflexões sobre o comportamento da fauna e flora em relação às modificações sofridas ao longo do tempo, oriundas ou não das atividades antrópicas. É curioso observar, por exemplo, que já naquela época a abundância de caranguejos era um fenômeno observado, bem como a existência de duas espécies de baratas, provavelmente introduzidas com o material de abastecimento da guarnição. Muitas são as advertências que faz quanto à introdução de espécies exógenas no ambiente confinado da ilha e suas prováveis consequências. Suas anotações estão longe do previsível relatório técnico puramente descritivo, visto estarem impregnadas de emoção e preocupação com o destino da ilha.

As pesquisas de Rudolf Barth resultaram em alguns trabalhos científicos inéditos, adiante relacionados, e nos dois relatórios, que transcrevemos a seguir. Eles deixam transparecer sua profunda preocupação com o futuro da ilha, nos alertas, nas constatações e recomendações absolutamente atuais. Houvessem sido seguidas teriam freado o desastre ambiental que já se anunciava.

\footnotetext{
2 BARTH-SCHATZMAYR, Ortrud Monika. Dr. Rudolf Barth, a vida de um cientista. Entomologia y Vectores, Rio de Janeiro, v.8, n.1, p.1-26. 2001. Para outras informações sobre Rudolf Barth, ver "Hermann Gonçalves Schatzmayr", disponível em: http://pt.wikipedia.org/wiki/Hermann_Gon\%C3\%A7alves_Schatzmayr, e "Rudolf Barth", disponível em: http://www.fiocruz.br/ioc/cgi/cgilua.exe/sys/start.htm?infoid=212\&sid=77.
} 


\section{Relatório de Rudolf Barth sobre a viagem à ilha de Trindade realizada no período de 26 de agosto a 13 de setembro de $1957^{*}$}

No período do dia 26 de agosto até 13 de setembro de 1957, tive a oportunidade de participar da viagem do Navio-Escola Almirante Saldanha para a ilha de Trindade.

Antes de entrar em pormenores, quero agradecer ao diretor do Departamento de Hidrografia e Navegação da Marinha do Brasil, almirante Jorge da Silva Leite, bem como ao vice-diretor, o comandante capitão de mar e guerra (CMG) Levy Penna Aarão Reis, pela gentileza com que me possibilitaram esta viagem a bordo do NE Almirante Saldanha, bem como pela permissão que tive de aproveitar-me de todas as instalações do navio. Não posso deixar de agradecer ao comandante do NE Almirante Saldanha, CMG José Santos de Saldanha da Gama, ao seu imediato, capitão de corveta Edimar Aché Cordeiro, bem como a toda a oficialidade do navio e da guarnição da ilha, pelo tratamento amigável que recebi e pela grande ajuda oferecida por todos.

\section{Resultados e observações}

Os resultados são de caráter provisório, pois ainda não foi possível realizar a classificação de todos os animais encontrados. Foram coletados, de preferência, os insetos da ilha; além disto, observamos e colecionamos espécies de todas as outras classes do reino animal. As observações deste relatório referem-se somente à fauna terrestre; o rico material marinho não foi incluído, pois merece um estudo especial.

\section{A) Fauna}

\section{Protozoa}

Foram tiradas 12 amostras de solo em várias formações geológicas. Até hoje foram analisadas somente quatro amostras, procedentes da região atualmente habitada.

1. Lodo do córrego da praia dos Portugueses:

Nematoda: 1 espécie

Diatomaceae: 13 espécies, muito numerosas

Flagellata (Phytomonadina): 4 espécies

Conjugales: 2 espécies

Ciliata: 5 espécies (extremamente pequenas)

Amoeba: 1 espécie

Thecamoeba (Testacea): 1 espécie (do grupo Neblina)

\footnotetext{
* Transcrição do relatório da primeira viagem de Rudolf Barth a bordo do navio-escola da Marinha Almirante Saldanha à ilha da Trindade em 1957. Posteriormente este relatório zoológico, acrescido de observações meteorológicas, climatológicas, geomorfológicas e biológicas feitas nessa viagem, foi publicado em junho de 1958 nas Memórias do Instituto Oswaldo Cruz, tomo 56, fascículo 1, páginas 261 a 289, compreendendo 21 ilustrações, várias de seu próprio punho.
} 
Cyanophyceae: 1 espécie

Esporos de Pteridophyta (samambaias): muitos

2. Terra seca do vale do córrego citado (altitude $50 \mathrm{~m}$ ):

Diatomaceae: 3 espécies, numerosas

Thecamoeba: 4 espécies: 1 espécie de Neblina, 1 espécie de Arcella, 2 espécies de Difflugia

Rotifera: 1 espécie (vive depois de 10 min. de infusão)

(a amostra possui muitos cristais de várias qualidades, desintegrados em partículas minúsculas)

Poucos esporos de samambaias

3. Terra seca, embaixo da vegetação rasteira de Waltheria americana (altitude: 100m):

Não foram encontrados Protozoa

Foram constatados alguns grãos de pólen

(a amostra possui poucos cristais minerais, mas sim muita substância inorgânica que, porém, se sedimenta rapidamente)

4. Horto, perto das habitações:

Diatomaceae: 2 espécies

Thecamoeba: 2 espécies: 1 espécie de Euglypha, 1 espécie de Arcella

Pólen

(a amostra possui muita substância inorgânica cujas partículas são extremamente pequenas, apresentando fortes movimentos brownianos; velocidade de sedimentação diminuída)

5. Resumo: As amostras possuem extremamente poucos microrganismos; a matéria inorgânica é pouco desintegrada; foi constatada, em todas as amostras, a presença de bactérias em número reduzido. As amostras, colhidas na época seca do inverno, indicam que as plantas não podem aproveitar da riqueza de minerais do solo em virtude da escassez de microrganismos. Precisa-se de uma observação na época mais úmida, a fim de comparação. Para melhorar o solo para possibilitar a horticultura em pequena escala, para abastecer um pequeno número de pessoas com legumes verdes, basta adubar a terra com estrume natural que contém, em geral, suficientemente os microrganismos.

\section{Vermes}

Além de poucos nematódeos do solo, foi encontrada uma espécie de Oligochaeta (minhoca comum), ainda não classificada. Vive esta espécie somente nas margens da parte baixa do córrego da praia dos Portugueses, onde o solo é mais úmido e humoso.

\section{Mollusca}

Foi encontrado grande número de caracóis de uma espécie de caramujo terrestre (vertente dos picos do Vigia e Nossa Senhora de Lourdes). Os animais vivos não foram localizados. Os caracóis acumulam-se nas ravinas, enterrados na areia; todos são bastante gastos, a cutícula e, principalmente, a camada prismática já desapareceram, de modo que podemos concluir que os animais morreram há alguns anos. Em cima do lugar onde se encontram os caracóis não existe nenhum vestígio de vegetação além de alguns restos de líquens que formam pequenas crostas sobre algumas pedras. 


\section{Arthropoda}

\section{Crustacea}

Além de uma espécie do grupo Catometopa (Brachyura), chamada 'siris', que vive na água salgada, encontramos duas espécies de crustáceos, característicos da ilha, dos quais o Grapsus grapsus, em grande número, vive nas pedras do banco coralino e da orla; esta espécie carnívora penetra, às vezes, na terra, por exemplo na praia do Príncipe onde foram encontrados muitos exemplares num lugar úmido (água doce), alimentando-se de musgos e algas. A outra espécie é Gecarcinus lagostoma, de preferência fitófaga, encontrada em grande quantidade em todas as partes da ilha até o alto dos picos, onde existe vegetação. Vivem estes animais embaixo de pedras, cavando tubos até um metro de profundidade, aproveitando da umidade existente aí, bem como da água de condensação que se precipita sobre a superfície das pedras durante a noite. As pedras acumulam o calor do sol e irradiamno rapidamente ao anoitecer de modo que a umidade se condensa nas superfícies mais frias do que o ar. A quantidade de água basta para escorregar e molhar a terra na base da pedra. Observamos várias vezes exemplares de Gecarcinus na primeira hora do dia, lambendo o líquido que pingou das pedras. Outro grupo de crustáceos são os isópodes que vivem embaixo de pedras em grande quantidade; constatamos várias espécies de Oniscidae e Armadillidiidae.

\section{Myriapoda}

Não foram observados diplópodes.

Nos Chilopoda ocorre uma espécie pequena que vive no mesmo ambiente dos isópodes.

\section{Insetos}

\section{Thysanura}

Uma espécie de Lepismatidae foi encontrada na 'casa do rádio' (animal introduzido). Dos Machilidae observamos uma espécie embaixo de pedras, nas praias dos Portugueses e dos Cabritos e perto da pedra do Tubarão. Várias espécies de Collembola vivem embaixo das pedras, em todas as partes da ilha.

Blattaria

Ocorrem nas casas, provavelmente introduzidas pelo material de abastecimento da guarnição, duas espécies de baratas: Blatta germânica e Periplaneta americana. Embaixo das pedras, na parte norte da ilha, vivem mais duas espécies, das quais uma, provavelmente Periplaneta australasiae, é muito frequente, enquanto que a outra (espécie áptera) é encontrada somente em alguns lugares em cima das residências.

\section{Orthoptera}

Nas pedras, ao longo das praias (dos Portugueses e do Andrada), ocorrem frequentemente muito exemplares de um grilídeo que não sobe nas encostas dos picos. Dos Acridiidae é muito comum o Schistocerca paranensis, o gafanhoto migratório que causa os grandes danos na Argentina, Uruguai e na parte sul do Brasil. Encontramos este ortóptero em grande quantidade em todas as partes onde existe qualquer vegetação, especialmente nas encostas em cima das praias dos Portugueses e do Andrada, no vale que dá para a praia do Príncipe, 
e no planalto em cima da praia dos Cabritos. A espécie, adultos e todos os estados larvais, ocorre em quantidade tão elevada que já hoje causa certos danos à vegetação, de maneira que, com uma reprodução destes animais um pouco mais elevada, a ilha corre perigo de enfrentar uma praga. Além desta espécie encontramos outra (braquíptera) em número reduzido.

Psocoptera

Uma espécie encontrada numa pedra do córrego da praia dos Portugueses.

\section{Anoplura}

Destes parasitas somente os cabritos possuem uma espécie, enquanto que em porcos e carneiros não observamos nenhuma espécie.

Chisopidae

Foi encontrada uma espécie na 'casa do rádio', atraída pela luz.

Dermaptera

Nas praias é comum a espécie Labidura riparia, que cava profundas galerias na areia. Encontramos esta em quantidades embaixo de pedras e, especialmente, em cadáveres de porcos.

\section{Homoptera}

No córrego da praia dos Portugueses, perto das casas, onde existem alguns metros quadrados de terra coberta por capim, vive uma espécie de Aphidae (pulgões da plantas), sempre visitadas por formigas do gênero Pheidole. No mesmo lugar encontramos algumas colônias de Coccidae.

Odonata

É comum uma espécie do gênero Aeschna, cuja larva encontramos frequentemente na água do córrego da praia dos Portugueses.

\section{Coleoptera}

$\mathrm{Na}$ água da praia dos Portugueses coletamos uma larva de um pequeno Hydrophilidae. Num cadáver de porco encontramos muitos exemplares de um dermestídeo, provavelmente Dermestes maculatus, adultos e todas as formas larvais. No mesmo ambiente vive um outro coleóptero, ainda não classificado (com larvas).

\section{Diptera}

Nas residências e arredores existem muitas moscas caseiras (Musca domestica, Drosophilidae, Eurioma erythrogaster, Lucillia, Piophila casei), introduzidas com o material da guarnição, e que se alimentam pelos esgotos e lixo e pelas fezes de origem animal e humana nesta região; depois do acabamento das novas construções e das instalações sanitárias o número destes possíveis transmissores de doenças contagiosas automaticamente diminuirá. Na 'casa do rádio', atraído pela luz elétrica, coletamos um pequeno tipulídeo e alguns exemplares de um nematócero pequeno. Sobre cadáveres, nos restos de comida e sobre fezes de animais e homens encontramos muitas outras formas de dípteros (Sarcophagidae etc.). Numa pedra, onde pouco antes passou um rebanho de cabritos observamos um exemplar de Hipoboscidae. 
Algumas larvas de Chironomidae ocorrem no lado das águas estagnadas do córrego da praia dos Portugueses e das duas represas do mesmo.

\section{Hymenoptera}

Observamos duas espécies de formigas, ambas muito frequentes, uma do gênero Pheidole, outra ainda não classificada. A Pheidole penetra frequentemente nas casas.

Lepidoptera

Formas diurnas não foram observadas. Formas noturnas: observamos muitas espécies de microlepidópteros, atraídos à noite pela luz, bem como durante as caminhadas pela vegetação rasteira das encostas. Verificamos que as larvas de várias espécies se alimentam de Waltheria americana, em cujos caules eles roem as suas galerias; em consequência disto existem muitas hastes desta planta mortas e secas.

São muito comuns várias (oito ou nove) espécies de Noctuidae, que, em centenas, chegam à luz ('casa do rádio', frigorífica) ou, mesmo durante o dia, voam entre as pedras das praias e sobre a vegetação. A espécie mais frequentemente encontrada é a Mocis repanda, cuja lagarta é conhecida como 'bicho do milho'; observamos esta larva comendo as folhas de várias plantas.

\section{Arachnida}

Observamos numerosas espécies de aranhas entre as pedras, na vegetação, bem como nas casas; porém não foram colecionadas por nós, pois, poucos dias antes, o especialista deste grupo dos artrópodes, doutor Wolfgang Buecherl, do Instituto Butantan, passou na ilha coletando os objetos de sua especialidade. Observamos que as aranhas se acumulam especialmente onde sempre há bastantes insetos, em geral dípteros.

Nas amostras de terra observamos algumas formas de ácaros de vida livre (Gamasiidae, Trombidiformes), porém em número muito reduzido. Ixodidae (carrapatos) não foram encontrados, pois todos os mamíferos da ilha, examinados por nós, não possuíam estes parasitas.

\section{Vertebrados}

Pisces

Peixes de água doce não existem na ilha.

Amphibia

Batráquios não foram observados.

Reptilia

O único réptil da ilha é a grande tartaruga Chelonia mydas, que, em abril e maio, vem do alto-mar às praias para desovar. Contamos na praia do Andrada, aproximadamente 750 antigas posturas, calculando o número total para toda a ilha em 1.500 até 1.600 posturas anuais. São as seguintes as praias visitadas pelas tartarugas: praia dos Portugueses (uma pequena parte a leste), praia do Andrada, praia das Tartarugas, praia do Príncipe, pequena praia antes do Paredão, praia do Paredão.

Quase todas as posturas (não observamos nenhum sinal de exceção) foram abertas pelos porcos, que devoraram quase todos os ovos, deixando apenas as cascas brancas, 
encontradas nos profundos buracos de um metro ou mais de diâmetro bem como, levado pelo vento, sobre a areia das praias. Poucos ovos, ocasionalmente não encontrados pelos porcos, completaram a evolução e os filhotes de quase 12 até $15 \mathrm{~cm}$ de comprimento, foram à água. Destes poucos somente alguns chegaram aí, pois o joão-grande (Fregata minor), gaivota de rapina, caçou alguns e os grandes siris decapitaram os outros ao chegar à orla (observações comunicadas pelo pessoal da guarnição da ilha). Encontramos alguns exemplares de filhotes decapitados. Uma postura de tartaruga conta de 150 até duzentos ovos. Continuando este massacre pelos porcos, no percorrer de poucos anos, o número de tartarugas continuará a diminuir até estes animais, documentos vivos de uma época paleontológica já passada há centenas de milhões de anos, desaparecerem do único lugar onde existem hoje em território brasileiro em número considerável. A dizimação dos filhotes pelos siris e aves é uma eliminação de medida natural que não representa nenhum perigo para a permanência deste animal inofensivo.

Aves

Todas as aves da ilha são formas marinhas. Observamos: Anous minutos (andorinha-domar), Fregata minor (joão-grande), Cygis alba (pombo-do-mar), Pterodroma arminjoniana (crazina), Sula sula (atobá-de-pé-vermelho), Sula dactylatra (atobá-de-face-preta).

O número dos exemplares de cada espécie é extremamente pequeno. Isto, provavelmente, está relacionado à pobreza em peixes que encontramos, pelo menos nesta época, nas águas costeiras da ilha. A grande parte dos peixes vive dentro da zona de arrebentação (peixes que se alimentam de corais), onde as aves não conseguem pescar. Observamos nidificação de aves nos seguintes lugares (sempre em paredes verticais, onde os gatos não podem subir):

Pico do Desejado: na vegetação arbórea do seu cume nidifica, provavelmente, a Sula sula (ninhos não encontrados; observação dos casais que, voando em linha reta, chegam de todos os lados do alto-mar e sempre procuram este pico alto).

Pico leste dos Cinco Farilhões: com exceção de Sula sula, todas as demais espécies. As paredes do pico, em grande extensão, são brancas pelas fezes.

Pico do Paredão: Anous minutus.

Pão de Açúcar: Anous minutus e Pterodroma arminjoniana.

Encontramos alguns pontos onde antigamente as aves nidificaram; as paredes destes lugares ainda demonstram as manchas brancas por causa das fezes.

Mammalia

Originalmente não viveram mamíferos na ilha.

Pelo homem foram introduzidas várias espécies: Mus musculus (camundongo caseiro), Felis ochreata domestica (gato doméstico), Ovis aries (carneiro), Capra hircus (cabrito), Sus scrofa domestica (porco doméstico).

Mus musculus: foi introduzido na ilha com o material de abastecimento; encontra-se agora nas casas e sob a madeira perto das novas construções.

Felis ochreata: existe em pequeno número. Observamos um exemplar na vertente leste do pico do Vigia, de cor preto-branca e de corpo muito forte. Foram encontrados frequentemente rastros do animal nas praias onde os gatos controlam a orla em procura de alimento que o mar joga à praia. 
Ovis aries e Capra hircus: não se sabe quem soltou os carneiros e cabritos na ilha. Atualmente estas duas espécies vivem em rebanhos de dez a trinta, às vezes até sessenta ou mais, andando em toda a parte da ilha onde se encontra vegetação. Observamos que os cabritos vão pastando bem nos cumes mais elevados da ilha como nas partes ao nível do mar (praia do Andrada), enquanto que os carneiros preferem mais as regiões altas e apenas raramente descem para as vertentes baixas. O número total de cabritos na ilha deve ser, aproximadamente, 250 até trezentas cabeças, o dos carneiros um pouco menor, talvez perto de duzentas. Estes dois herbívoros alimentam-se de todos os componentes da vegetação com exceção das samambaias; observamos os cabritos devorando mesmo as plantas espinhosas das praias. O alimento principal são as folhas de Waltheria americana que, em grande extensão, reveste algumas colinas e o planalto em cima da praia dos Cabritos. As cabras, além deste pasto, comem também as folhas das poucas árvores e roem as cascas dos troncos, como conseguimos observar no pico de Trindade e nos troncos mortos que foram levados pela água para os vales; nestes troncos podem-se observar ainda hoje as marcas dos dentes dos cabritos. O estado físico das duas espécies não é excelente, porém não são magras. A estrutura de corpo não se difere da das formas que o homem cria; somente o pelo é mais comprido, especialmente o dos velhos bodes. A carne dos cabritos e carneiros é de boa qualidade.

Sus scrofa: os porcos, segundo os antigos documentos, foram introduzidos já em 1700 pelo astrônomo inglês Halley, mas as expedições seguidas (navio Vênus, 1784; Ross, 1839 e outros) provavelmente, soltaram também alguns exemplares. O porco doméstico, descendente do javali europeu, é do ponto de vista hereditário um animal instável, isto é, num ambiente livre, sem o cuidado do homem, depois de certo número de gerações, ele volta mais e mais à forma primitiva. Observamos este fato nos porcos abatidos na ilha durante a viagem, bem como nos cadáveres e nas ossadas encontradas frequentemente. Os sinais de forma selvagem são, além do comportamento, os seguintes, comparados com os da forma caseira: região do ombro mais alta e forte do que a da bacia; musculatura do pescoço reforçada; frente da cabeça e crista do nariz quase em linha reta; focinho prolongado; presas fortes e muito divergentes; cristas occipitais (inserção da musculatura do pescoço) muito salientes; pelo duro, comprido e preto; corpo comprimido lateralmente; orelhas eretas.

Alimentam-se os porcos, como provou o exame do conteúdo de estômago, de preferência de vegetais, especialmente de rizomas e raízes de Waltheria americana e de outras plantas não identificadas, bem como e folhas e raízes de ciperáceas. Além dos ovos de tartarugas, comem também cabritos e carneiros caídos e filhotes dos mesmos. Sinais de canibalismo não foram observados. Não acredito que eles devorem muitos peixes, pois a carne de dois exemplares, que comemos aí estava excelente e gostosa, sem sabor de peixe; pode ser que, em outras épocas do ano, o mar jogue mais peixe às praias; faltam-nos ainda observações para a comparação. 


\section{B) Observações ecológicas}

A vegetação da ilha está em forte regressão. Os antigos documentos de visitantes dos séculos XVIII e XIX falam de matas de pau-brasil e outras madeiras em regiões extensas. Sem tomar em consideração estas notícias, em parte duvidosas, várias observações provam esta regressão:

Em toda parte da ilha encontramos, nas ravinas, córregos e canions (vales encaixados), muitos troncos mortos, com diâmetro de 25 até $30 \mathrm{~cm}$. Estes troncos são testemunhas do dessecamento contínuo que, por sua parte, favorece e acelera a erosão. A causa do começo deste processo da destruição da terra é, sem qualquer dúvida, o resultado da introdução dos grandes animais que desequilibraram a natureza original da ilha. Encontramos tais troncos na grande ravina que desce do pico das Grazinas onde hoje somente crescem algumas pequenas samambaias e ciperáceas, mas nenhuma árvore. O mesmo fato ocorre nos profundos canions e ravinas que cortam as vertentes dos picos Verde e Vermelho, que hoje estão completamente sem revestimento vegetal. A erosão começou pela pastagem dos rebanhos de cabritos e carneiros que, não somente diminuíram o crescimento da vegetação rasteira, que cobria e protegia o solo, mas também pela caminhadas dos animais; por meio destes foi cortado o revestimento da terra de modo que o sol atingiu o solo, dessecando, e a água pluvial e o vento na época seca começaram a levar a terra humosa. Roendo a casca das árvores e comendo as folhas, os cabritos diminuíram a mata. (Não encontramos sinais de incêndios). Logo o lençol subterrâneo de água caiu e numerosas plantas desapareceram em grandes extensões. (Fatos paralelos conhecemos dos países mediterrâneos). Os porcos, em busca de raízes, fossaram a terra abrindo ainda mais o revestimento do solo; estes lugares, com 1 a $2 \mathrm{~m}$ de largura e 3 a $5 \mathrm{~m}$ de comprimento, encontramos frequentemente, e sempre observamos como a erosão começa o seu trabalho abrindo em seguida novas ravinas. Quanto mais profundo este sulco pluvial, tanto maior é a área que perde toda a umidade. Observamos, no morro do Paredão, nos dois lados de uma ravina de $3 \mathrm{~m}$ de profundidade e $5 \mathrm{~m}$ de largura, faixas entre 8 e $10 \mathrm{~m}$ de largura sem qualquer vegetação. Neste mesmo morro, a vegetação termina entre 100 e 120m de altitude; em cima desta linha até o cume, perto da cratera, não encontramos nenhuma planta viva; mas aí, em $217 \mathrm{~m}$ de altitude, aparecem ainda antigas raízes de Waltheria americana a $30 \mathrm{~cm}$ de profundidade.

No vale que entra, na praia das Tartarugas, entre morro do Paredão, Pão de Açúcar, picos Nossa Senhora de Lourdes e do Vigia e morro das Tartarugas, encontramos quantidade de mamoneiros (planta introduzida). Apenas três exemplares estão vivos, o resto morto. O mesmo fato observa-se perto das habitações e no vale do córrego da praia dos Portugueses. Isto indica que estas plantas em épocas passadas há apenas poucos anos, encontraram condições muito mais favoráveis do que hoje.

Na praia das Tartarugas, o vento constante do mar para a terra está transportando grande volume de areia que se desloca permanentemente em direção ao pico do Vigia, formando uma verdadeira duna migratória cujo cume está hoje já perto do citado pico.

Em 1916 foram indicados cinco córregos permanentes: um na praia dos Portugueses, três na praia do Príncipe e um na enseada da Cachoeira. Em 1950 foram encontrados somente dois: o da praia dos Portugueses e o da enseada da Cachoeira. Nós encontramos apenas um córrego, na praia dos Portugueses com atualmente cinco a oito litros por segundo, que 
abastece as habitações. Os córregos da praia do Príncipe não deixaram nenhum sinal da sua antiga existência; encontramos nesta praia, perto do marco de Benjamin Constant, um lugar úmido onde pingam algumas gotas de água, que logo desapareceram na cinza vulcânica; de todos os lados convergem trilhas de cabritos e carneiros para este lugar, um sinal que este é o único ponto com água doce em toda a região. O repórter Arnauld Pierre, passando do pico de Trindade em direção aos Cinco Farilhões, encontrou um córrego que leva as águas dos picos Desejado e de Trindade para o mar, e viu outro menor que desce dos picos Sapé e Verde. Um terceiro com muito pouca água existe entre os Cinco Farilhões.

A existência destes fios de água depende da vegetação. Esta, por sua vez, será destruída em poucos anos pela erosão que ataca em grande escala já nas elevações mais elevadas, como se pode ver, aproximando-se do alto-mar: grandes partes das paredes desmoronaram recentemente, as respectivas marcas são bem visíveis. Cada tentativa da vegetação de recuperar o terreno perdido é cortada pelos animais. As duas matas existentes no pico Desejado e no pico de Trindade estão em plena regressão como provam os troncos caídos e a galharia morta, encontrados em suas vertentes.

Para salvar a terra, a ilha precisa de duas operações imediatas:

1. eliminar todos os animais introduzidos: porcos, cabritos e carneiros; a carne pode ser aproveitada;

2. plantar árvores resistentes ao longo e, especialmente, na cabeceira do córrego da praia dos Portugueses para proteger o solo deste vale (amendoeiras, oliveiras, jaqueiras, eventualmente taquaruçu).

Além de árvores, pode ser interessante plantar capim, ciperáceas e outras plantas que revestem o solo; em cada caso, porém, exclusivamente tais plantas que são componentes da flora original da ilha, pois por espécies introduzidas correremos novamente o perigo de desequilibrar a composição sociológica primitiva, adaptada ao clima da ilha.

\section{C) Observações climatológicas}

Todas as observações biológicas foram feitas na época do inverno. Infelizmente não conhecemos ainda nada da climatologia da ilha. Com a construção de postos meteorológicos obteremos, depois de um ano de funcionamento, um aspecto, ainda provisório, da distribuição e quantidade de precipitações. Isto já permite algumas conclusões mais exatas sobre a possibilidade de recuperar a terra, hoje perdida pela erosão. As observações sobre a intensidade e direção principal dos ventos são, também, de grande interesse. Mas um ciclo de um só ano de observações meteorológicas não é suficiente, pois não sabemos nada sobre a periodicidade do clima, que é de grande importância não somente a respeito da ilha, como também para os nossos conhecimentos sobre a climatologia do continente e do oceano.

Observamos, do ponto de vista meteorológico, alguns fatos interessantes que se referem à ilha bem como ao continente:

Durante toda a época da nossa viagem, existia uma camada de inversão em aproximadamente $2.000 \mathrm{~m}$ de altitude, evitando a convecção subir mais e causando uma estratificação das nuvens neste nível. Em virtude disto, as precipitações são limitadas, e realmente caíram apenas poucas chuvas passageiras sobre o mar e a ilha. 
Em relação direta com a direção dos ventos, observamos formações de nuvens sobre as encostas dos picos, trazendo certa quantidade de água que se condensa aí.

Comparações entre direção do vento e pressão barométrica permitem conclusões diretas sobre a translocação do anticiclone atlântico e, com isto, previsões sobre o movimento das frentes trazidas pelos ciclones continentais em uma antecedência de três até cinco ou mais dias. Estas previsões são necessárias não somente para o Serviço Nacional de Meteorologia, porém muito interessantes para a navegação e aviação internacional. Um posto climatológico permanente na ilha modificará muitos dos nossos conhecimentos, ainda incompletos, sobre os movimentos de massas de ar do Atlântico, sobre a influência do nosso clima pelo ar frio de origem africana (corrente de Benguela) e sobre a zona dos alísios cuja fronteira meridional, no inverno, corresponde à região da ilha e, no verão, passa para o sul de Trindade. A fim de controlar as propriedades do clima do Atlântico, por meio de rádio-sondagem, justamente a ilha de Trindade é o único lugar existente nesta zona.

Para formar um aspecto completo das condições biológicas da ilha, necessitamos ainda observações em outras épocas do ano e, a fim de comparação, uma visita do arquipélago de Martim Vaz cuja fauna e flora não foram modificadas pela ação do homem.

\section{Resumo}

a. As observações faunísticas, florísticas e climatológicas formam um aspecto incompleto da ilha. Necessitamos ainda de observações em outras épocas do ano e, ainda, do arquipélago de Martim Vaz, bem como de dados meteorológicos de alguns anos consecutivos.

b. A vegetação da ilha e, concomitantemente, a parte fértil da terra, estão desaparecendo pela influência de animais introduzidos (porcos, cabritos e carneiros). Para possibilitar habitações permanentes em pequena escala, são necessárias duas operações imediatas:

1) diminuir ou, melhor ainda, eliminar por completo estes animais cuja carne é comestível;

2) plantar árvores pelo menos na parte habitada e no córrego que abastece a guarnição.

c. O solo é rico em minerais, porém pobre em microrganismos. Para horticultura basta uma adubação por estrume natural e cal, que existe em quantidade na ilha em forma de recifes coralinos.

d. De vários pontos de vista (ecológicos, climatológicos, de navegação e aviação, de previsão de tempo no continente, da pesca, etc.), torna-se aconselhável de manter na ilha um posto permanente de meteorologia e rádio-sondagem.

Rio de Janeiro, 23 de setembro de 1957.

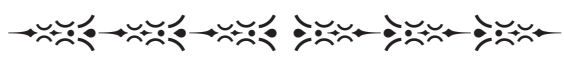




\section{Relatório de Rudolf Barth sobre a viagem à ilha de Trindade realizada no período de 23 a 29 de junho de 1959*}

Em continuação dos estudos iniciados no ano de 1957 como parte do programa do Ano Geofísico Internacional, realizado pela Marinha de Guerra, acompanhei outra viagem à ilha de Trindade, a bordo da corveta Solimões, a fim de comparar as modificações que a ilha sofreu no percorrer dos últimos dois anos, e para colaborar com o colega Henrique Pimenta Veloso num estudo da microfauna do solo em relação ao revestimento das várias formações vulcânicas.

O navio partiu do Rio de Janeiro em 23 de junho de 1959, e chegou na ilha em 26 de junho. Devido ao mar grosso, conseguimos desembarcar somente no dia seguinte. Percorremos, em observação, apenas a parte oriental da ilha até o Paredão do Túnel e as colinas ao sul da praia das Tartarugas. Sendo a viagem retardada por motivos técnicos, o comandante do navio resolveu voltar para Rio na noite do mesmo dia, aproveitando-se, para a viagem de retorno, do tempo que amainou durante o dia. Fomos a bordo com a última balsa, e o navio suspendeu às vinte horas, chegando ao Rio de Janeiro no dia 29 do corrente.

\section{Resultados zoológicos}

As espécies de insetos, colhidas e observadas, são as mesmas que foram encontradas na viagem anterior. Nas praias, com milhares de cavações de desovas das tartarugas (Chelonia mydas), observamos um sarcofagídeo em grande quantidade (o material foi entregue ao doutor Hugo Souza-Lopes). Este díptero foi encontrado, em 1957, apenas esporadicamente. Nos cadáveres de animais (tartarugas, tubarão, crustáceos) sempre encontramos dermápteros (Labidura riparia), coleópteros do gênero Dermestes (aparentemente maculatus) com as larvas respectivas. Culicídeos não foram observados, também as poucas águas estagnadas não contêm larvas.

Das aves foram observadas as mesmas espécies de 1957. Também os lugares de nidificação são os mesmos, pelo menos na parte oriental da ilha. Não foram abatidos pássaros para procura de insetos hematófagos.

Como propusemos em relatório da viagem anterior, dirigido à Marinha, Departamento de Hidrografia e Navegação, o número de porcos semiselvagens foi bastante reduzido nos últimos dois anos. Não aparecem mais nas praias, concentrando-se mais na parte de oeste. Assim, as posturas das tartarugas não foram destruídas pelos porcos, e a vegetação rasteira (tipo de restinga) (ver relatório de H.P. Veloso) começa a invadir as areias das praias. Os rebanhos de cabritos foram, também, reduzidos. Observamos somente um, com 26 cabeças,

\footnotetext{
* Transcrição do relatório da segunda viagem de Rudolf Barth à ilha da Trindade em 1959. Este relatório nunca foi publicado.
} 
bem como alguns exemplares isolados. Os carneiros retiraram-se para as partes ocidentais da ilha, onde ainda existem pequenos pastos em regiões quase inacessíveis para o homem.

A respeito dos porcos observamos que existem dois grupos de aspectos diferentes e bem distinguíveis: o primeiro, criado, em alguns exemplares, em cativeiro na ilha, difere do porco doméstico atual somente pelos pelos, mais grossos e densos, e pelo hábito de viver; porém é fácil sua domesticação. O segundo corresponde às formas descritas no relatório da primeira viagem; suas características anatômicas assemelham-se claramente às do javali europeu, o que se refere à configuração física, especialmente do esqueleto: parte anterior mais alta que a parte posterior, crânio com cristas transversais do vértex muito elevadas, presas grandes, linha vértex-frontal quase reta e muito inclinada, corpo comprimido lateralmente. Esta última forma de porco retirou-se, durante os dois últimos anos, do lado oriental da ilha, ainda não explorada e quase inacessível. Sem tomar em consideração as poucas referências a respeito do histórico dos porcos, e baseando-se no aspecto anatômico, temos a impressão que houve várias introduções em diferentes épocas.

Foram encontradas conchas de duas espécies de moluscos terrestres (material enviado ao doutor Hugo Souza-Lopes), bem como conchas de Nautilus sp. Planorbídeos não existem, aparentemente, na ilha, senão no regato da Cachoeira, não explorado até hoje.

Durante todo o rumo de Cabo Frio até a Ilha de Trindade, observamos, além de tubarões e outros peixes, grande número de baleias. Conseguimos identificar, pelo menos, duas espécies: o cachalote, Physeter catodon, e a baleia cinzenta, Rhachianectes glaucus (sem nadadeira dorsal). Todas foram encontradas isoladas, raras vezes em grupo de dois ou três exemplares. O tamanho é de 10 a $15 \mathrm{~m}$, aproximadamente. Isto indica que se trata de exemplares semiadultos que se acumulam, conforme a época e as correntes marítimas, em águas que contêm suficientemente alimentos, como é de esperar nesta região ao sul da zona dos alísios, onde entram em contato várias correntes marítimas de temperaturas diferentes.

Em virtude das poucas horas de nossa estadia em terra, conseguimos coletar apenas pouco material, como crânio e ossos de tartarugas, crânio de gato semiselvagem, e filhotes vivos de tartaruga.

Rio de Janeiro, 1o de julho de 1959

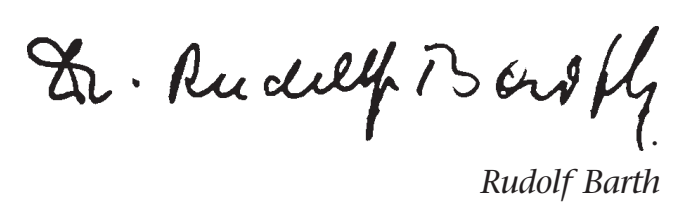




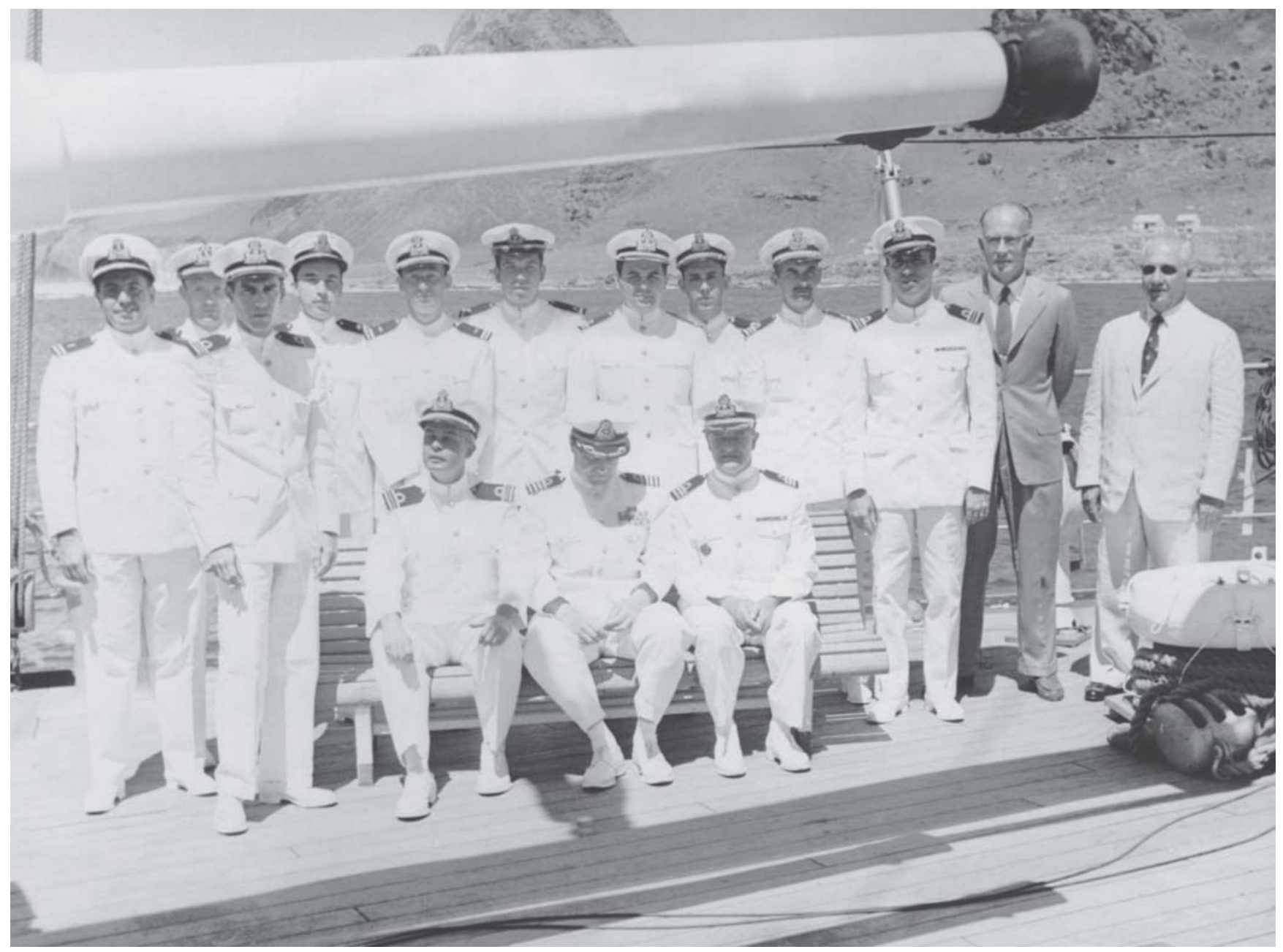

Figura 1: Foto oficial a bordo do NE Almirante Saldanha, da Marinha do Brasil. Rudolf Barth é o segundo à direita (Arquivo pessoal de Rudolf Barth)

Figura 2: NE Almirante Saldanha, da Marinha do Brasil (Foto: Rudolf Barth/arquivo pessoal de Rudolf Barth)

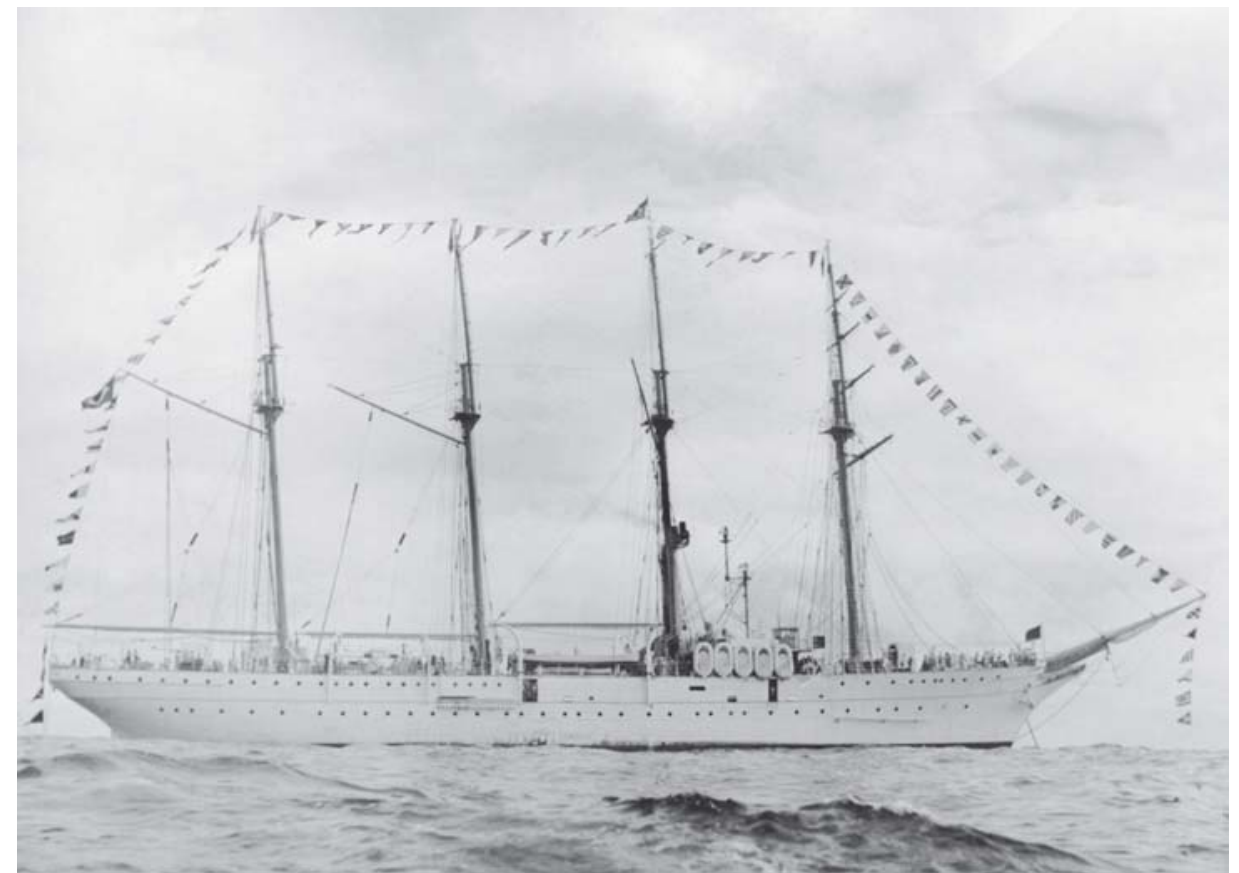



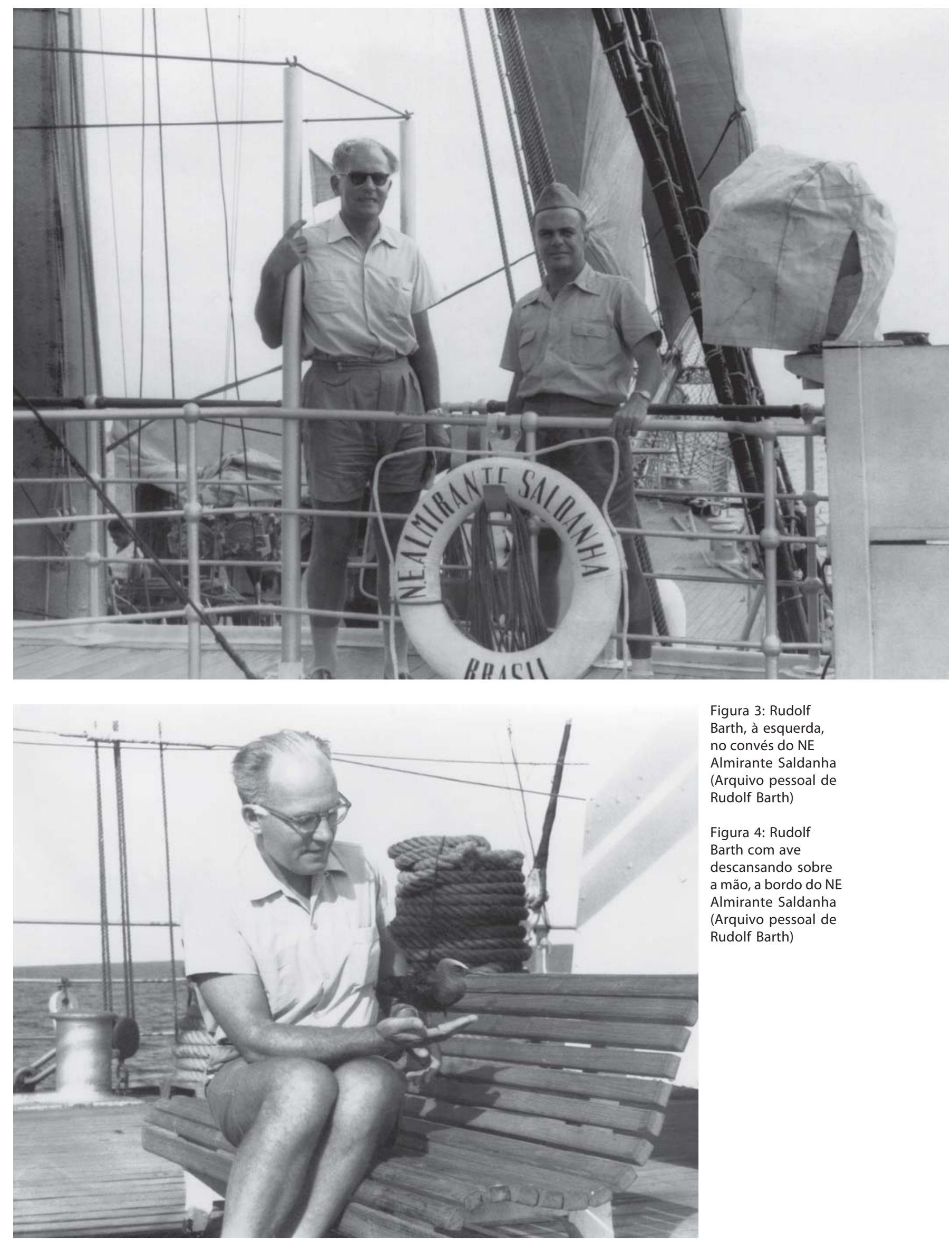

Figura 3: Rudolf

Barth, à esquerda,

no convés do NE

Almirante Saldanha

(Arquivo pessoal de

Rudolf Barth)

Figura 4: Rudolf

Barth com ave

descansando sobre

a mão, a bordo do NE

Almirante Saldanha

(Arquivo pessoal de

Rudolf Barth) 


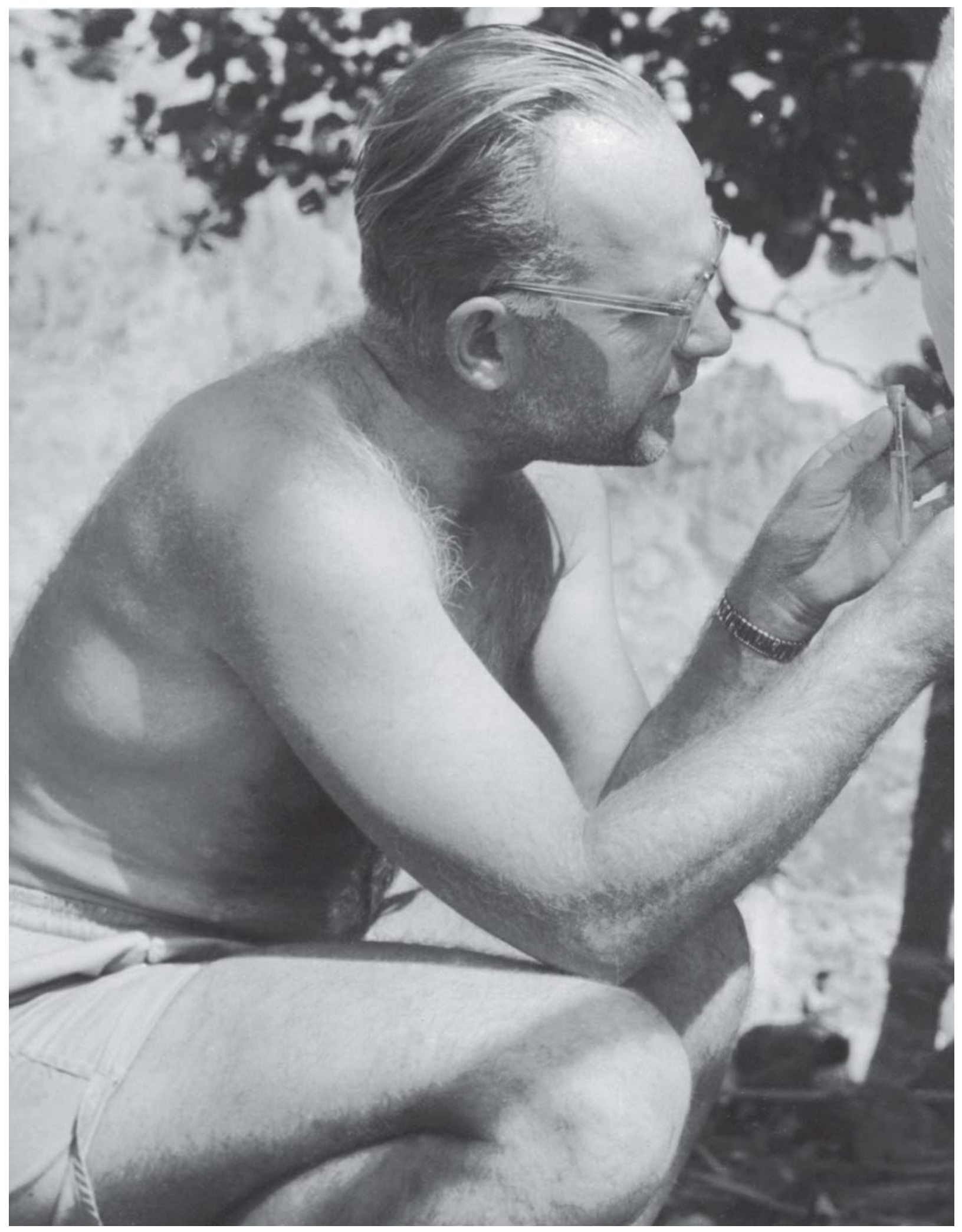


Rudolf Barth

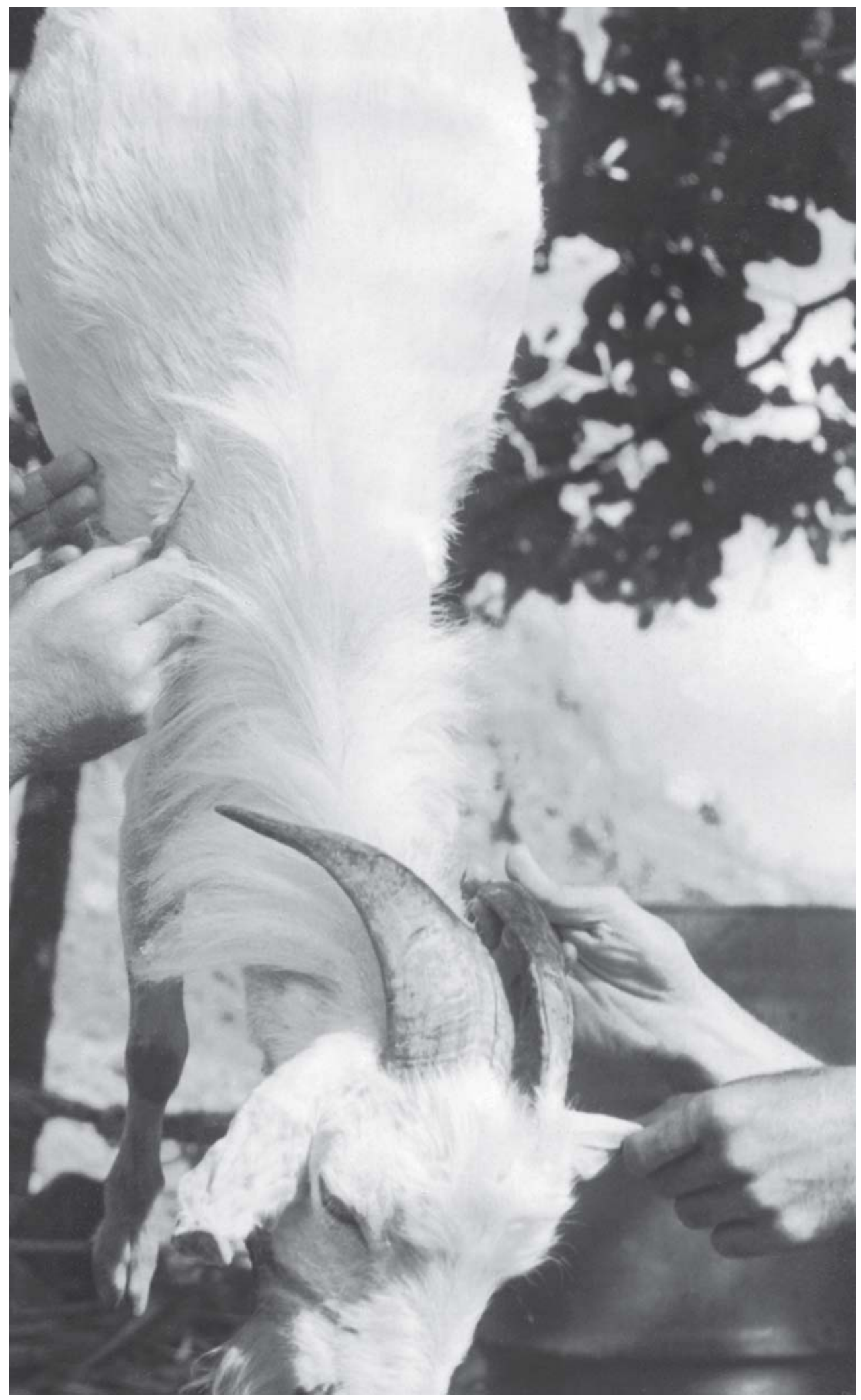

Figura 5: Rudolf Barth coletando parasitas de

uma cabra na ilha da

Trindade (Arquivo

pessoal de Rudolf Barth) 


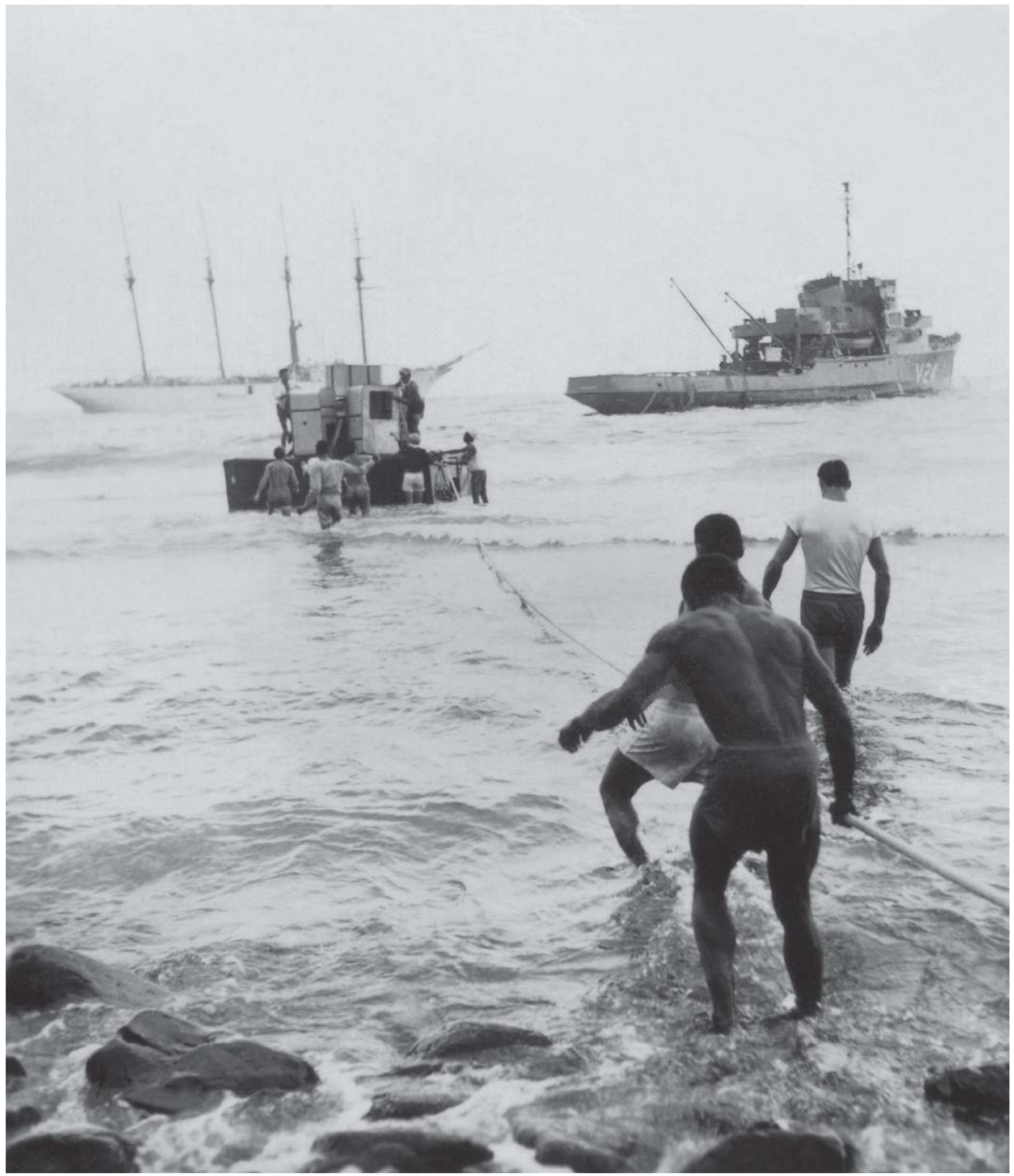




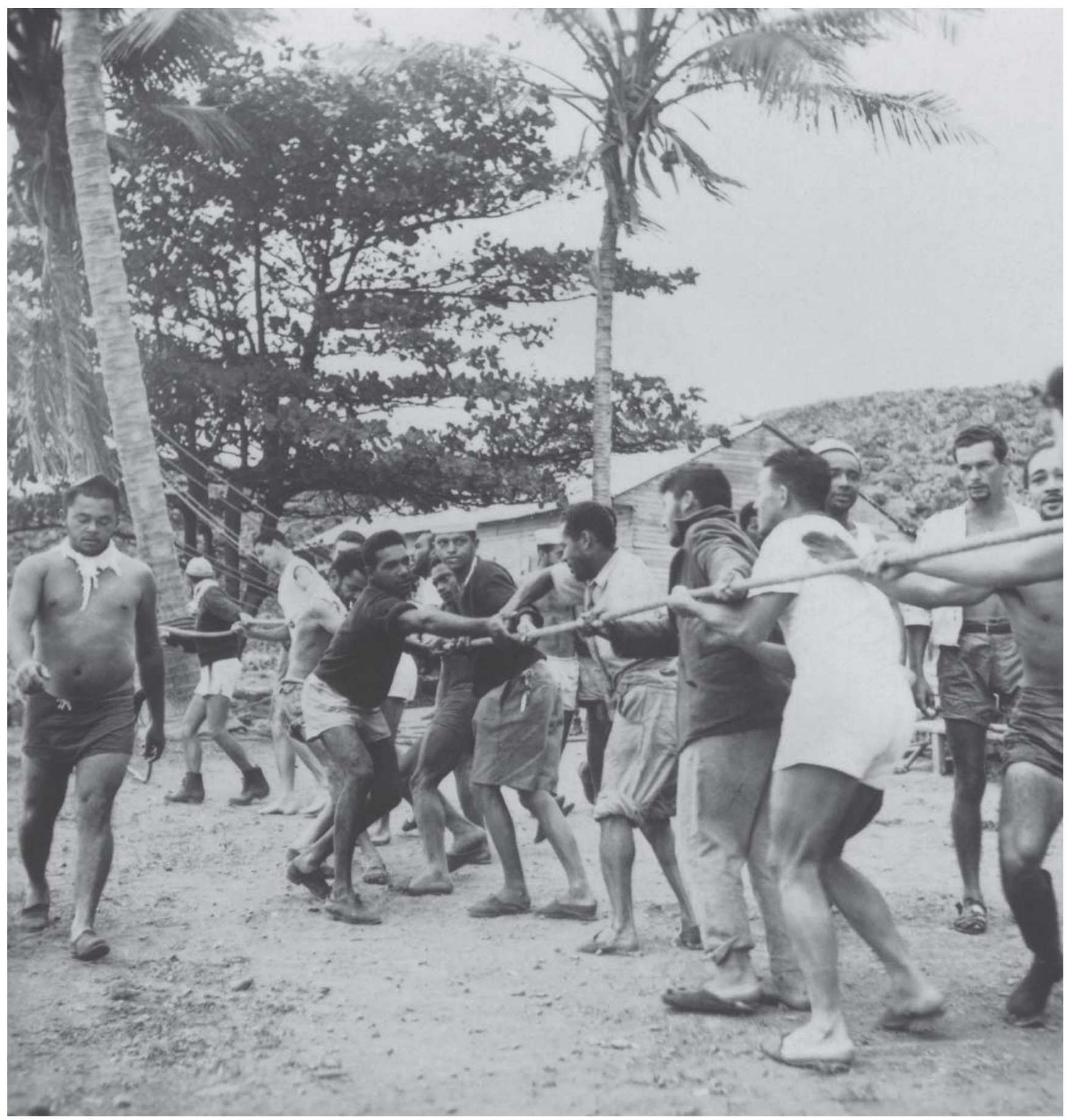

Figura 6: Ao fundo o navio NE Almirante Saldanha, mais à frente uma corveta da Marinha do Brasil e uma balsa sendo puxada por marinheiros em terra através da arrebentação, desembarcando material vindo do Rio de Janeiro (Foto: Rudolf Barth/ arquivo pessoal de Rudolf Barth)

Figura 7: Esforço no desembarque na ilha (Foto: Rudolf Barth/arquivo pessoal de Rudolf Barth) 


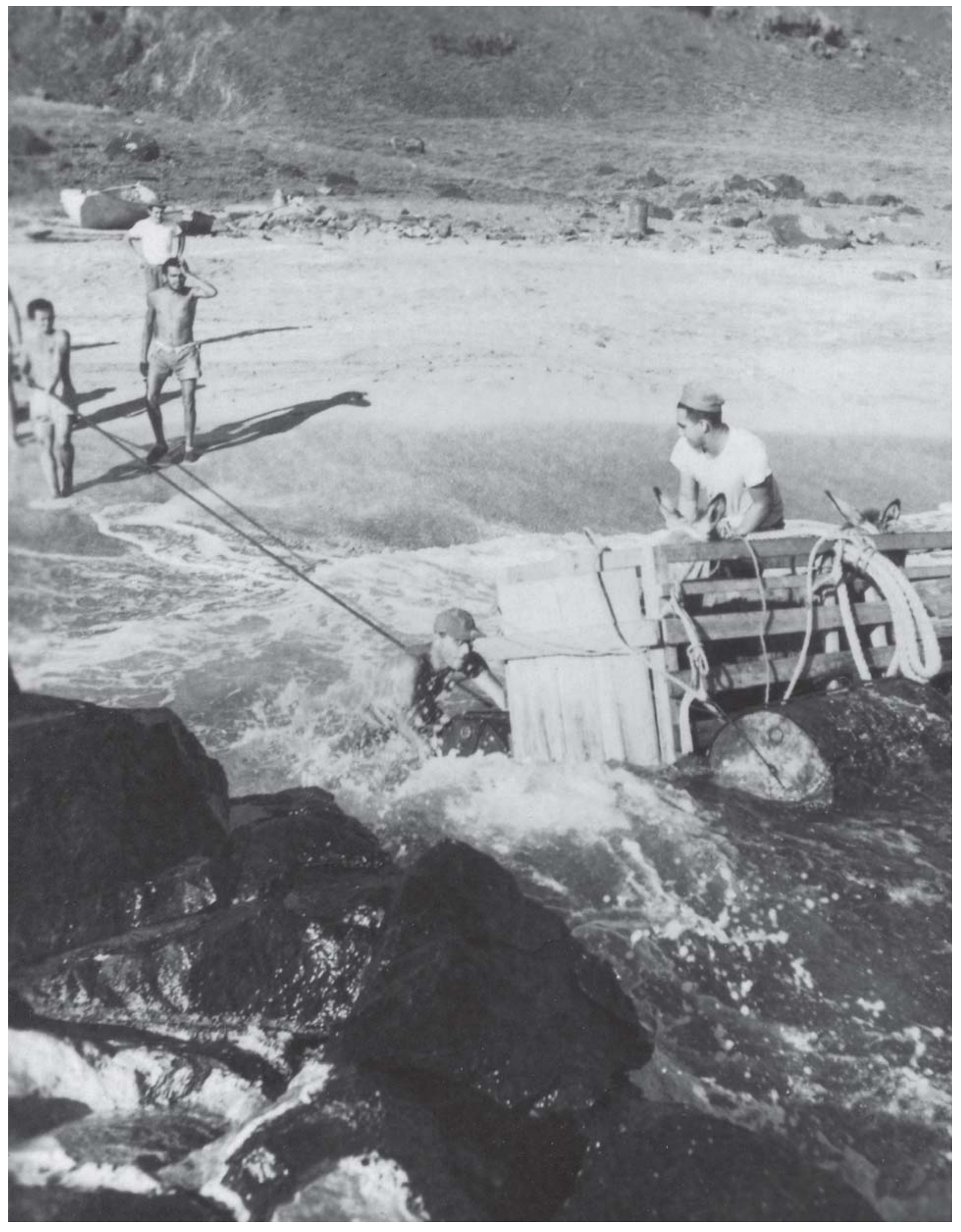




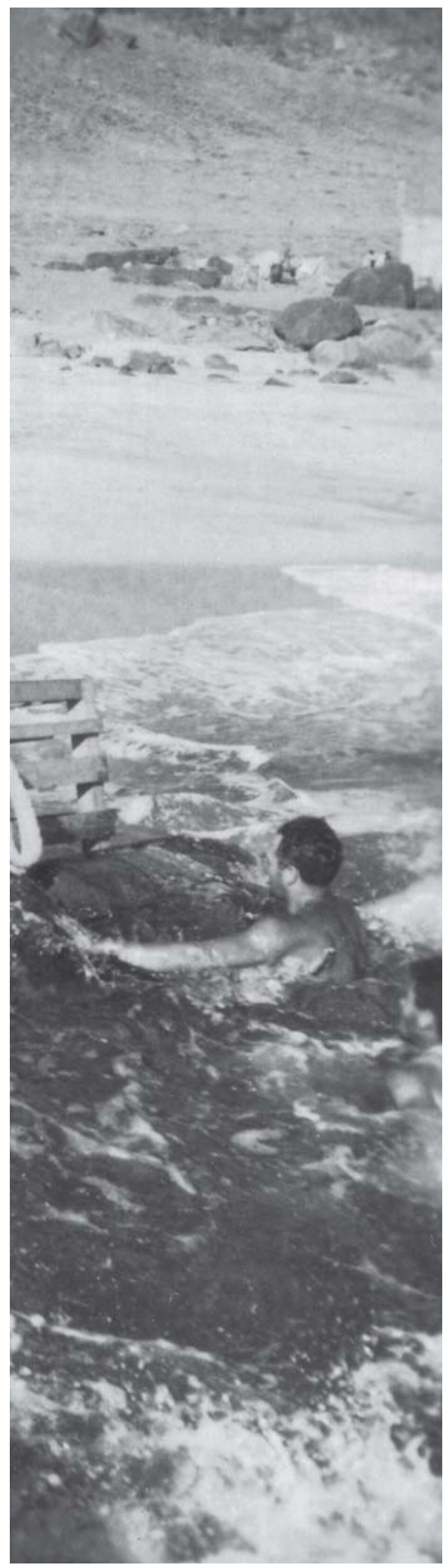

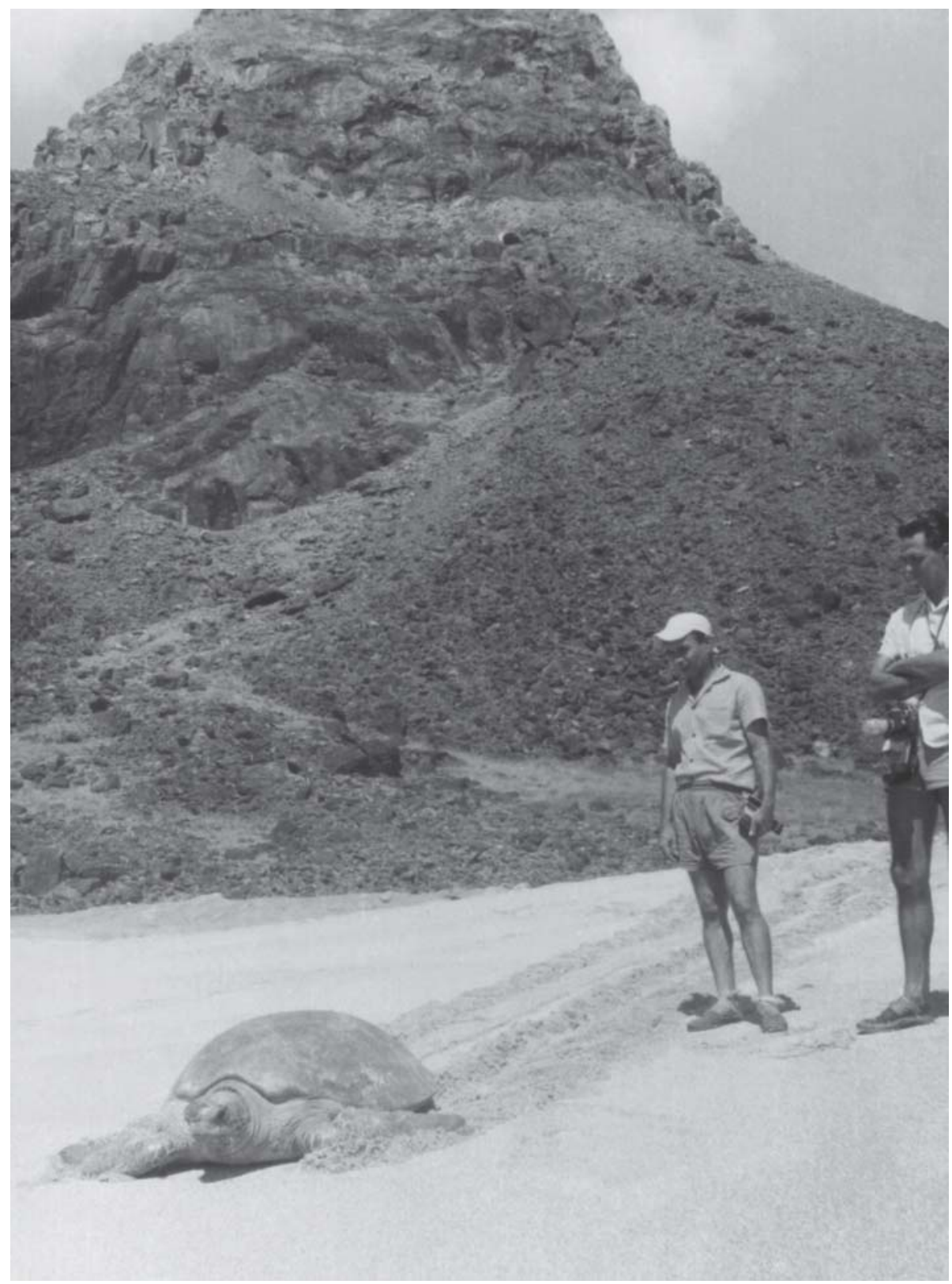

Figura 8: Desembarque

de dois jumentos na balsa

(Foto: Rudolf Barth/arquivo

pessoal de Rudolf Barth)
Figura 9: Tartaruga na

ilha de Trindade (Arquivo pessoal de Rudolf Barth) 


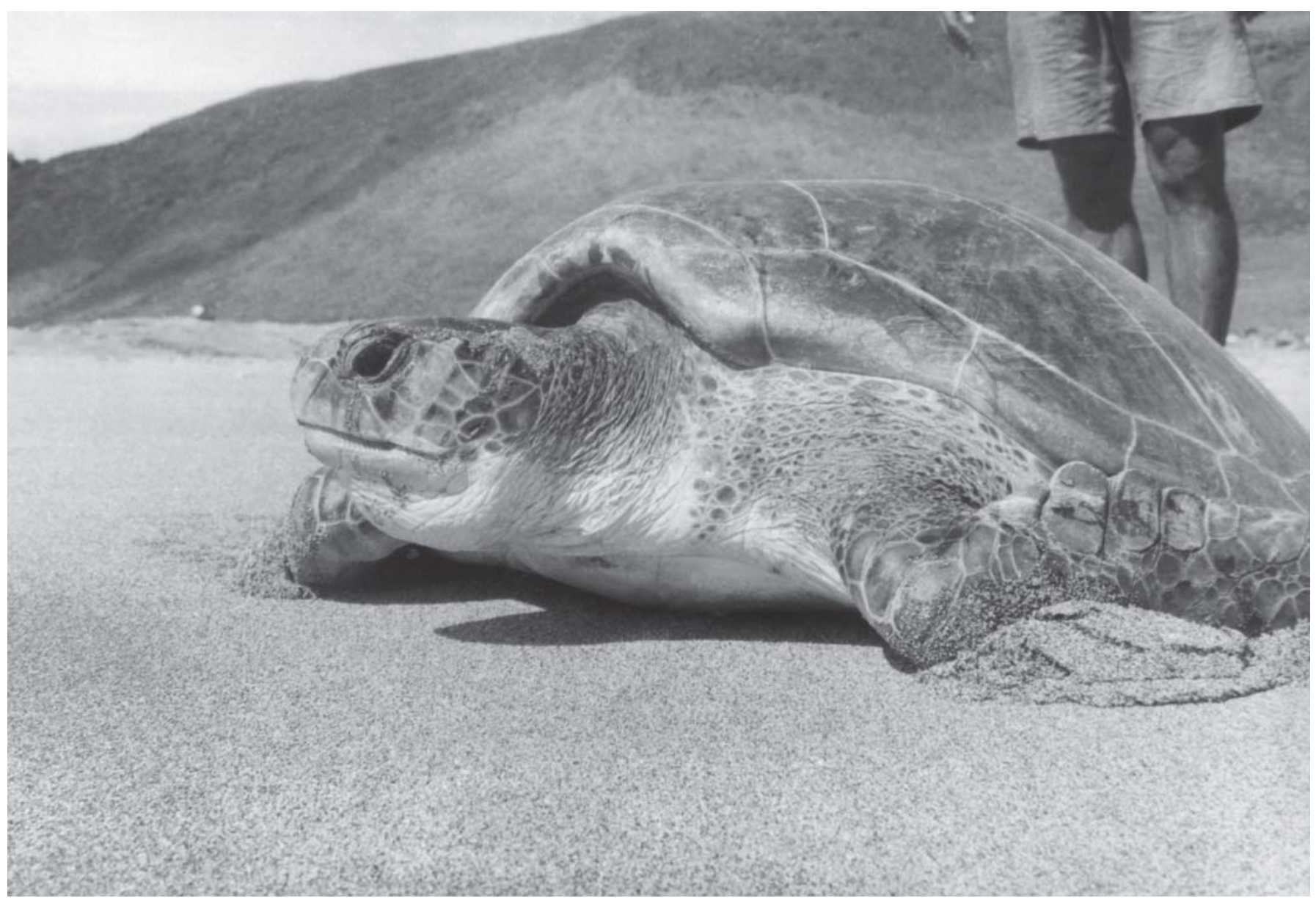

Figura 10: Tartaruga-verde (Chelonia mydas), única espécie de réptil localizada por Rudolf Barth na ilha da Trindade (Arquivo pessoal de Rudolf Barth)

\section{PUBLICAÇÕES DE RUDOLF BARTH SOBRE A \\ ILHA DA TRINDADE:}

BARTH, Rudolf.

Observações biológicas e meteorológicas

feitas na ilha de Trindade. Memórias do Instituto Oswaldo Cruz, Rio de Janeiro, v.56, n.1, p.261-289. 1958.

BARTH, Rudolf.

Observações biológicas e meteorológicas feitas na ilha de Trindade. Anais Hidrográficos, Rio de Janeiro, v.12, p.121-149. (reimpressão). 1959.
BARTH, Rudolf.

Observações sobre a grande tartaruga marinha Chelonia mydas L., feitas na ilha de Trindade. Anais da Academia Brasileira de Ciências, Rio de Janeiro, v.34, p.405-410. 1962

BARTH, Rudolf.

Beobachtungen an einer verstuemmelten Schildkroete Chelonia mydas L. Anais da Academia Brasileira de Ciências, Rio de Janeiro, v.34, p.411-413. 1962.

\section{$\rightarrow \rightarrow \rightarrow<<$}

